\title{
Change of Postmodern Paradigm in Cultural studies and Socio-cultural Practice
}

\author{
Elena Olegovna Kuznetsova', Natalia Evgenevna Shafazhinskaya ${ }^{2}$, Alexander \\ Vladlenovich Kamenets 3 , Elena Anatolyevna Meleshkina³, Natalia \\ Gennadievna Orlova ${ }^{3}$
}

${ }^{1}$ Russian State Pedagogical University named after A. I. Gertsen, Saint Petersburg, Russia

${ }^{2}$ Razumovsky Moscow State University of Technologies and Management, Moscow, Russia ${ }^{3}$ Russian State Social University, Moscow, Russia

\begin{abstract}
:
The proposed article is devoted to the problem of changing the postmodern paradigm in cultural studies and socio-cultural practice as opening new prospects in solving urgent problems of life and development of cultural heritage. The authors of the article consider the possibility of the postpostmodern study of interaction processes as the main research focus, developing and creatively rethinking the postmodern achievements of cultural processes and phenomena. The proposed new paradigm bases significantly expand the views of researchers studying the sociodynamics of culture in the field of forecasting cultural processes and socio-cultural design in various spheres of human practice. The discussed paradigm may be of particular interest for the development of problems in the field of ethics and the solution of modern environmental problems, which remain among the least studied in cultural studies and cannot be comprehensively considered in the framework of postmodern approaches.
\end{abstract}

Keywords: postmodernism, postpostmodernism, interaction, cooperation, communication, culture, society.

\section{Introduction}

Contemporary cultural studies continue to discuss the emerging new cultural paradigm, which is replacing the postmodernism prevalent in cultural studies and various socio-cultural practices. This new paradigm is most often defined as postpostmodernism, which does not have an unambiguous interpretation, but has some essential features that need further understanding and study. Postmodernism, which replaced modernism in cultural studies, insisted on some fundamentally new foundations in cultural studies. Among them, it is possible to single out maximizing the principle of human freedom, which is not a break with many established cultural traditions, which does not have a corresponding philosophical justification as is customary in modernism, but a secondary reflection of the achievements of human culture, which is not connected by any ideological dogmas and ideological bias.

The emergence of serious environmental risks emerged in this freedom proclaimed by postmodernism, both in research and creative practice that arose as a manifestation of limitless forms of self-expression that threaten the very existence of a person (Anufrieva et al., 2016). Thus, postmodernism, as originally opposed to the suppression of freedom and the physical destruction of man by totalitarian regimes, fell into its trap of surrender to the totalitarianism of arbitrariness in all its manifestations as one of the consequences of globalization. There is a need to create a new 
cultural paradigm that overcomes the extremes of rationalized revolutionary activity of modernism and the socio-ecological irresponsibility of postmodernism.

\section{Proposed Methodology}

\subsection{General description}

This paradigm, called "postpostmodernism", is an attempt to find a synthesis between postmodernism and modernism based on the identification of their common features, among which researchers distinguish the following: primary interest in socio-cultural dynamics, but not the statics of cultural events and phenomena; refusal of attempts to study and build historical and cultural universals and emphasis on modern social and cultural processes; correlation of global and local changes in culture and society; diagnosis of modern socio-cultural reality as devoid of certainty and predictability (Berger and Luckmann, 1995; Bergson, 2006; Vernadsky, 2003; Davydova et al., 2018).

At the same time, there is an increasing need to establish causal relationships in the study of emerging tensions and conflicts in modern society, the main symptom of which is the gap between the various levels of social interaction, primarily between the micro-level represented by the world of everyday existence and the macro level in the form of institutional structures. The gap between these levels in the context of globalization is steadily increasing, which leads to increased confrontation between groups representing the vital interests of people and institutional and state structures that operate according to their logic, often far from the interests of "ordinary people".

In the research aspect, this gap is fixed as the absence of the relationship between ordinary and theoretical knowledge. The latter is mainly focused on the study of the institutional level (macro-level) of social reality, not related to its non-institutional level (microcosm). Postmodernism attempts to bridge this gap through a total negation in modern society, the value of institutionality that threatens the well-being of people (it is sufficient to recall the brilliant analysis in the works of M. Foucault on the repressive social institutions of the state against the people that do not fit into dominant ideas about mental normality), has not solved this problem (Foucault, 2005; Shveitser, 1973; Shcherbakova et al., 2016).

In fact, postmodernism has proclaimed every individual who can be an independent creator of their being, free from soulless regulation and strict regulation as a universal human right to "incorrectness" in solving their life problems. This is the right of each person to their own "marginality", which becomes the only ecological niche for many creative subjects in the conditions of a mechanized and depersonalizing society with its total control and unambiguous hierarchy.

This turn in cultural studies has led to a fundamental change in the postmodernists of many of the methodological foundations of cultural studies. These changes are well known: the study of the decentered and deterritorial socio-cultural space, deontologization of history, replacement of historical time by the study of its cultural context, rejection of the concept of progress, development, historical and cultural cycles in explaining the dynamics of cultural processes (Deleuze and Guattari, 2008).

\subsection{Algorithm}

Such grounds were found when taking into account the phenomenon of "other" in cultural studies, interaction with which is an integral attribute of human existence as a subject of culture. In this case, "other" should be understood not only as the existence of a real subject, with which one or another member of society constantly deals (this can be a boss, parent, friend, colleague, family member, etc.), but also a "mental" subject, present even in zones of physical loneliness in the form of self-reflection, conscience, ideal, etc., which is generated by all the cultural and spiritual experiences of mankind. It is the ability to meaningfully interact with the "other" in this broad 
interpretation that makes up the main condition for the preservation and development of social and cultural norms in modern society. Refusal of such interaction with the "other" leads to selfisolation and insecurity of the individual before unpredictable life circumstances since it is the "other" who presents the necessary sociocultural experience to remove the uncertainty that is dangerous for the individual existence (Goffman, 2004; Kamenets, 2015; 2018).

Along with the category of "other" in the postpostmodern paradigm, the concept of "living environment", which is interpreted as necessary conditions for the physical, social, and mental wellbeing of an individual, begins to take center stage, which corresponds to the generally accepted understanding of human health (World Health Organization). Moreover, given that the vast majority of diseases are of a mental nature, mental well-being is basic for providing medical care for a wide variety of diseases. Accordingly, a favorable "living environment" in this case is, first of all, the acquisition of the possibility of mental health, where the most significant is the emotional background of the individual's existence, which is formed in the process of interaction with others.

It is characteristic that the appeal to the mental problems of the personality in postmodernism was mainly associated with mental, but not emotional disorders (it suffices to recall the work on the problems of the madness by M. Foucault).

The next key category for the emerging paradigm of postpostmodernism is "interaction", without which it is impossible to focus on the "other", as well as a full-fledged "living environment" as a sphere of the psychic ("mental"). It should be noted that in the sociological and cultural literature on the problems of interactions, it often comes down to communication and is seen in the subject of symbolic interactionism, which currently is inadequate for studying processes of interaction.

The growing gap between communication and real social action at both the global and local levels can be considered a sustainable trend. Typical examples are the widespread policy of "double standards" and "fake information," which hides the true intentions of the authors of certain messages in international politics (global level) and the huge number of divorces, which indicates that promises of mutual love and fidelity originally declared by young spouses for various reasons turn out to be unrealized later in their real everyday interaction (local level).

It is possible to add to it a common situation of total mutual social insanity in various discussions, "talk shows", where opponents, observing the appearance of dialogue "do not hear" each other, defending their own "truth" and in reality seek to impose their point of view, etc. In this regard, the crisis of international diplomacy and the crisis of the word, which no longer has such a meaning in modern society, replaced by real behavioral pragmatics, are not accidental.

It is proposed in the emerging postpostmodern perceptions in cultural studies not only to fix the differences between social interaction and communications but also to identify the relationships between them. The result of such a relationship is proposed to consider interaction, which contains both communicative and behavioral components (Kamenets et al., 2016; Foucault, 1997; Sherbakova et al., 2016).

It is also important to note that the concept of interaction means not just the interchange of actions and communicative acts, but a change in the state of all participants in the interaction (internal and external), where everyone is equal, which eliminates the reduction of interaction and communication to unilateral behavioral and communicative impact, where one of the participants in this process is assigned the role of an "inanimate" or "object" close to it. Subjectivity is possessed only by one who needs to be obeyed under any circumstances and to whom one must also obey under any circumstances. This one-sidedness in interaction is especially evident in pedagogy and the international behavior of countries claiming world domination.

\section{Result Analysis}


In the postpostmodern paradigm, it is proposed to consider interaction as the initial "molecule" of all social and cultural processes, since, as noted above, a person, if they have not become completely schizophrenic (as postmodern suggests, contrasting the innocuousness of "schizophrenia" with the dangerous "paranoia" of modernity), is never "alone". This manifests its inevitable sociality and the ability to reflect with an eye "to the other".

The macrocosm oversaturated with simulacra also generates phantom objects of research, artificial entities, up to the full leveling of the "human factor". A peculiar effect of a curved mirror is created, which researchers are increasingly taking for reality itself, but it has long been replaced by constructed virtuality using a variety of information technologies. For example, the opinion of one of the prominent researchers of "large systems", T. Parsons, would be extremely interesting, in relation to the modern USA, torn by endless contradictions that threaten the very cultural identity of the American people (for example, what is the emergence of "black racism", about which no one has recently could have thought).

As a prospect for such research, it is possible to cite examples of literary dystopias of the 2oth century, where the demonstration of the "defeat in rights" of the heroes of these dystopias for personal happiness reveals the main problems and trends of the corresponding society. Classical literature also provides great material for research. Thus, describing mainly the private life of several noble families, L. Tolstoy gave a deep artistic analysis of the war of 1812 . K. Marx, as is known, dreamed of writing an economic work devoted to capitalism on the works of O. Balzac, which he put above most of professional economic research. A new research situation that arose after reassessing the universality of the heuristic possibilities of postmodernism was graphically presented in the corresponding Table 1 by the famous culturologist and anthropologist E. A. Orlova (2010, p. 398).

Table 1. Change of cultural paradigms.

\begin{tabular}{|c|c|c|c|}
\hline Bases & Modern & Postmodern & New direction \\
\hline $\begin{array}{l}\text { Human position } \\
\text { in relations with } \\
\text { the world }\end{array}$ & $\begin{array}{l}\text { active individual } \\
\text { subject }\end{array}$ & $\begin{array}{l}\text { the active individual } \\
\text { is the subject } \\
\text { (existential } \\
\text { abandonment) }\end{array}$ & $\begin{array}{l}\text { participation as a party to the } \\
\text { interaction }\end{array}$ \\
\hline Activity goal & $\begin{array}{lr}\text { transforming } & \text { and } \\
\text { improving } & \text { the } \\
\text { environment } & \\
\end{array}$ & $\begin{array}{l}\text { testing the strength } \\
\text { of existing orders }\end{array}$ & $\begin{array}{l}\text { ordering relationships with the } \\
\text { environment }\end{array}$ \\
\hline $\begin{array}{l}\text { Activity } \\
\text { environment }\end{array}$ & $\begin{array}{l}\text { world as a whole } \\
\text { unity }\end{array}$ & $\begin{array}{l}\text { heterogeneous socio- } \\
\text { cultural space, } \\
\text { indefinite intertext }\end{array}$ & $\begin{array}{l}\text { heterogeneous social and } \\
\text { cultural space, recognition of the } \\
\text { importance of both actual and } \\
\text { virtual reality }\end{array}$ \\
\hline $\begin{array}{l}\text { Means of solving } \\
\text { problems: }\end{array}$ & $\begin{array}{l}\text { fully controlled by } \\
\text { the laws of nature }\end{array}$ & $\begin{array}{l}\text { trials and errors in } \\
\text { the rejection of } \\
\text { universal methods }\end{array}$ & $\begin{array}{l}\text { reflexive interaction with the } \\
\text { environment, the construction of } \\
\text { relationships with it }\end{array}$ \\
\hline $\begin{array}{l}\text { Results of the } \\
\text { activity }\end{array}$ & $\begin{array}{l}\text { socio-cultural } \\
\text { system object }\end{array}$ & $\begin{array}{l}\text { virtual reality with } \\
\text { non-directional } \\
\text { movement (rhizome) }\end{array}$ & $\begin{array}{l}\text { formation of sociocultural orders } \\
\text { commensurate with man, the } \\
\text { microdynamics of the life world }\end{array}$ \\
\hline $\begin{array}{l}\text { Consequences of } \\
\text { activity }\end{array}$ & $\begin{array}{l}\text { increasing } \\
\text { uncertainty due to } \\
\text { unintended }\end{array}$ & $\begin{array}{l}\text { further increase of } \\
\text { uncertainty, anomie } \\
\text { at the realization of }\end{array}$ & $\begin{array}{l}\text { organized fine-structured the } \\
\text { dynamic reality, anthropic life } \\
\text { world }\end{array}$ \\
\hline
\end{tabular}




\begin{tabular}{|l|l|l|l|}
\hline & $\begin{array}{l}\text { consequences of } \\
\text { targeted changes }\end{array}$ & $\begin{array}{l}\text { heterogeneity of } \\
\text { sociocultural reality }\end{array}$ & \\
\hline
\end{tabular}

\section{Discussion}

The change of a person's position in relation to the world from individual activism in favor of interaction is considered in the new cultural paradigm as overcoming inner loneliness, fixed by postmodernism. Thus, the main character of "The Glass Bead Game" Knecht goes into the world to feel needed by someone not as a professional of the game, but as a teacher ready to take responsibility for the "other". The sophisticated intellectuality and isolation from the problems of real society, achieved by postmodernists, has led many of them to a widespread sense of existential abandonment and their lack of demand by real society. The main problems of our time (environmental, economic, military, etc.) began to unfold outside the research field of postmodernists, who were not ready for a deep study of these problems in the direction of their solution. The concept of discourse introduced by postmodernists themselves did not receive further development and meaningful content, limiting researchers to virtual game spaces. The appeal to the situation of interaction creates prerequisites for achieving consensus in solving problems relevant to human existence.

The socio-cultural environment of individuals is changing, which is no longer perceived as some kind of integrity (modern), as a heterogeneous socio-cultural space and an indefinite intertext created on its basis, but with the recognition of a heterogeneous socio-cultural space, the significance of equally relevant current and virtual reality, which are necessary for the processes of social interaction, where virtuality (for example, fantasy, imagination, mental characteristics) is varied in combination with real behavioral characteristics. In this case, it is taken into account that any individual belonging to the human race is a "centaur-object", combining the world of "visible", "bodily" and "invisible" (soul-spiritual).

The choice of means of solving actual problems in the socio-cultural reality is also changing. Modernism throughout its history has evolved as a desire to rely on nature itself in order to achieve the desired results. Postmodernism has fixed the unreliability of these means due to the increasing unpredictability of both nature itself, deformed by the person, and the person themself, using nature to the detriment of both themself and the natural environment surrounding them.

Recognition of the importance of both actual and virtual reality is the fixation within the new paradigm of reality of the "invisible world" created and produced by the person as an immutable fact - in the form of mental characteristics of the person, the world of creative imagination, ideological and value attitudes, etc. not always expressed in the appropriate behavioral manifestations or if expressed, then very indirectly. The right of the individual to their inner world is confirmed as the recognition of the same right in another interacting subject. Thus, the phenomenon of mutual exchange and mutual realization of the cultural potential of interactors, necessary for the actualization of stable and unambiguously interpreted cultural meanings and imports important for all parties to the process of interaction, is formed.

The study of the possibilities of such a relationship within the framework of the new paradigm shows that it is possible through the study of intermediate social levels linking global and local socio-cultural phenomena (Kamenets, 2017). This is the meso level. Moreover the global level itself, in turn, should, in this case, be correlated with the mega-level. By the presence of the corresponding social actors functioning at each of these levels, we obtain the following theoretical possibilities of "ascent" and "descent" from one level to another.

Micro-level is associated with the presence of an "existential subject" who interacts with others in non-institutional and informal interpersonal space (as a relative, family member, friend, lover, believer, etc.). 
Meso-level is associated with the presence of a "public or civil subject", whose interaction with others implies a relative balance of informal and social-role interactions. This level is often referred to as the so-called "third sector" in socio-cultural practice, which is the basis for the formation of civil society. It is at this level that cultural identity is gained due to the sense of "we", in contrast to "others", with which it is also important to carry out fruitful and diverse interactions (Pereverzeva, 2012; Davydova et al., 2018; Pereverzeva et al., 2018).

At the macro-level (across the whole society), legal personality is acquired in the process of interaction, in which informal, non-voluntary relationships are minimized and partnerships come into force, suggesting a reasonable compromise and consensus in order to achieve common goals. At this social level, the ability to sacrifice private interests in the name of common values is manifested. The degree of this sacrifice is determined by the prevailing morality and the dominant spiritual and moral values in society.

The mega-level (general civilization, "universal") social level of interaction means the transfer of the latter mainly to the value-worldview plane and implies a willingness for spiritual asceticism and sacrifice in the name of general humanistic ideals. In this case, the interactors are open to the "whole world" as opportunities to serve each of its representatives, manifestations of attention, sympathy, compassion for each individual, regardless of their social status, cultural level, or beliefs. It should be noted that achieving this level of interaction is difficult to achieve in a real society. Therefore, there is no accidental departure from the active interactions of many interactors in "ecological niches", where such a ministry is possible.

Each of the interactors can exist at one or another level of social reality, depending on the given situations of social interaction, which have socio-anthropological significance and have been studied in relevant studies. It is important to note that the processes of socio-cultural interaction will be effective if they are included in the relevant cultural contexts that are mastered by the interactors (spiritual and cultural experience).

\section{Conclusions}

When developing the postmodern attitude that "nothing is new under the sun", the attitude to the cultural and spiritual heritage of mankind, in this case, is formed as advanced knowledge about desirable models, strategies, forms, etc. of socio-cultural interaction, which is becoming culturallike and, at the same time, innovative (Orlova, 2010; Sherbakova et al., 2014). Moreover, the latter is determined by the socio-anthropological significance (at least, the task of self-preservation) for the interactors themselves, each of which experiences their own "life drama", often requiring nonstandard solutions.

The analysis of the possibilities for the emergence of a new cultural paradigm was based on the statement of the urgent need to confront modern challenges and threats to the very existence of mankind, the essence of which is to assert the "right of the strongest" at all social levels as a cultural norm of human existence. It is becoming increasingly difficult to negotiate a sensible solution to vital problems because of the breakdown of social and cultural ties between parties pursuing their own interests and goals. Without diminishing the importance of such studies, it should still be noted that not always communicative processes, as noted above, reflect the real social behavior of communicants and often only exacerbate the existing tension and social disadvantage in the modern world.

The proposed postpostmodern paradigm also opens up new possibilities for studying cultural processes at all levels of social interaction and as an opportunity to study the mechanisms of the dynamics of transition from one level to another, which is not only theoretical but also of undoubted practical value (Pereverzeva, 2012; Davydova et al., 2018; Pereverzeva et al., 2018). 


\section{References}

Anufrieva, N.I., Kamenets, A.V., Scherbakova, A.I., Zorilova, L.S., Zinchenko, E.O. (2016). Prospects of Further Evolution of Culturology. Rupkatha Journal on Interdisciplinary Studies in Humanities, $8(3), 85-96$.

Berger, P., Luckmann, T. (1995). Sotsialnoe konstruirovanie realnosti [The Social Construction of Reality]. Moscow: Medium, 324.

Bergson, H. (2006). Tvorcheskaya evolyutsiya [Creative evolution]. Moscow: Kuchkovo pole, 384.

Davydova, A.A., Lushnikov, S.S., Pereverzeva, M.V., Smirnov, A.V., Tsarev, D.V. (2018). Piano music of composers-minimalists in the teaching repertoire of higher music education. Opcion, 34(17), 149162.

Deleuze, G., Guattari, F. (2008). Antiedip. Kapitalizm i shizofreniya [Anti-Oedipus. Capitalism and Schizophrenia] Ekaterinburg: Faktoriya, 672.

Foucault, M. (1997). Istoriya bezumiya v klassicheskuyu epokhu [Madness and Civilization: A History of Insanity in the Age of Reaso]. St. Petersburg: University book, 576.

Foucault, M. (2005). Nuzhno zashchishchat obshchestvo [Society must be defended]. St. Petersburg: Science, 312.

Goffman, E. (2004). Analiz freimov [Frame Analysis]. Moscow: Institute of Sociology, Russian Academy of Sciences, 752.

Kamenets, A.V. (2015). Vvedenie v teoriyu sotsialnogo vzaimodeistviya [Introduction to the theory of social interaction]: monograph. Moscow: Publishing house of RSSU, 464.

Kamenets, A.V. (2017). Vliyanie urovnya sotsialnoi realnosti na reshenie aktualnykh problem obshchestva sredstvami sotsialnogo vzaimodeistviya [The influence of the level of social reality on the solution of pressing problems of society by means of social interaction], in: Khudozhestvennoe prostranstvo kultury tretego tysyacheletiya: problemy nauki i obrazovaniya [Artspace of the culture of the third millennium: problems of science and education]: Collection of scientific works of the faculty of arts and socio-cultural activities of the Russian State Social University. Vol.1. Moscow: Buki-vedi, 42-52.

Kamenets, A.V. (2018). Izuchenie sotsialnykh vzaimodeistvii kak perspektiva sovremennykh kulturologicheskikh issledovanii [The study of social interactions as a perspective of modern cultural studies], in: Istoricheskie povoroty kultury [Historical turns of culture]: collection of scientific articles. Moscow: "Soglasie" Publishing House, 415-422.

Kamenets, A.V., Anufrieva, N.I., Ganicheva, Yu.V., Kazakova, I.S. (2016). Metodologicheskie i kontseptualnye osnovaniya issledovanii fenomenov sotsialnogo vzaimodeistviya $\mathrm{v}$ obrazovanii [Methodological and conceptual foundations of research on the phenomena of social interaction in education]. Scientific notes of the Russian State Social University, 15(1(134)), 85-93.

Orlova, E.A. (2010). History of anthropological teachings. Moscow: Academic project, 621

Pereverzeva, M. V. (2012). Kanadskaya muzyka XX veka: puti razvitiya [Canadian Music of Twentieth Century: Development Paths]. SShA i Kanada: Ekonomika. Politika. Kultura [USA and Canada: Economics. Politics. The culture], 2, 85-104.

Pereverzeva, M., Anufrieva, N., Shcherbakova, A., Anufriev, E. (2018). USA music as a reflection of the national sociocultural values, in: A. Maloletko, N. Rupcic, Z. Baracskai (Eds.), Economic and Social Development. 34th International Scientific Conference on Economic and Social Development XVIII International Social Congress (ISC-2018): Book of Abstracts. Moscow: RSSU, 125-126.

Shcherbakova, A.I., Anufrieva, N.I., Meleshkina, E.A., Korsakova, I.A., Kamenets, A.V., Ivanova, E.Yu. (2016). Kulturologiya v sisteme gumanitarnogo znaniya [Culturology in the system of humanitarian knowledge]. Monograph. Moscow: Buki-vedi, 314.

Sherbakova, A.I., Kamenets, A.V., Anufrieva, N.I., Anufriev, E.A., Zinchenko, E.O. (2016). Methodological Paradigm of Social Interaction as the Basis for Modern Education Resources Research. International Review of Management and Marketing, Review of Management and Marketing, 6(S3), 140-145.

Sherbakova, A.I., Kamenets, A.V., Zinchenko, E.O. (2014). Potetial of Musical and Pedagogical Analisis of Socio-cultural Interaction Processes. Asian Social Science Special Issue, 10(24), 144-150.

Shveitser, A. (1973). Kultura i etika [Culture and ethics]. Moscow: Progress, 342. 
Vernadsky, V.I. (2003). Biosfera i noosfera [Biosphere and noosphere]. Moscow: Airis Press, 576. 